\title{
BIBLIOMETRIC STUDY ON METALURGI: MAJALAH ILMU DAN TEKNOLOGI PUBLISHED DURING 2016-2020
}

\author{
Rochani Nani Rahayu* \& Yupi Royani* \\ *National Research and Innovation Agency (PDDI), Indonesia \\ Email:nanipdii@yahoo.com,yupi_rdd@yahoo.co.id \\ (Submitted: 08-02-2021, Revised: 19-11-2021, Accepted: 24-11-2021) \\ DOI: $10.24252 / \mathrm{v} 9 \mathrm{i} 2 \mathrm{a} 3$
}

\begin{abstract}
ABSTRAK: Analisis bibliometrik dilakukan terhadap Metalurgi: Majalah Ilmu dan Teknologi periode 2016-2020. Sumber data diakses dari situs http://ejurnalmaterialmetalurgi.com/. Fokus kajian ialah total artikel tiap tahun, pengarang, institusi, kota asal, penulis produktif dan kata kunci. Data diolah menggunakan Ms. Excel. Hasil penelitian menunjukkan bahwa jurnal ini telah menerbitkan sebanyak 78 artikel. Total artikel terbanyak ditulis secara berkolaborasi 4 orang (17 judul;21,79\%) dan paling sedikit ditulis secara berkolaborasi 7 orang (8 judul; $10,25 \%)$. Adapun artikel yang ditulis secara individu sebanyak 10 judul $(12,82 \%)$. Nilai derajat kolaborasi rata-rata adalah $\mathrm{C}=-0,87$. Efendi Mabruri merupakan penulis paling produktif. Institusi penelitian berkontribusi di jurnal ini adalah LIPI dan Sultan Ageng Tirtayasa. Kota tempat penulis bekerja terbanyak ada di Tangerang. Kata kunci terbanyak adalah Microstructure 15 kali $(3,51 \%)$ dan kata kunci yang mengandung kata Nickel berturut-turut adalah Nickel alloys sebanyak $4(0,95 \%)$, Nickel ores sebanyak $2(0,47 \%)$, Nickel plating sebanyak 2(0,47\%), dan Nickel Hidroxyde $1(0,23 \%)$. Kesimpulan penelitian yaitu jurnal Metalurgi menerbitkan artikel terbanyak dari LIPI, demikian pula dengan peneliti yang paling produktif juga berasal dari LIPI, dengan artikel sebagian besar ditulis secara berkolaborasi.
\end{abstract}

Kata kunci: Bibliometrika; metalurgi; nikel

ABSTRACT: This bibliometric studied Metalurgi : Majalah Ilmu dan Teknologi, a serial publication managed by Metallurgical and Materials Research Center LIPI. The data were observed through https://ejurnalmaterialmetalurgi.lipi.go.id/, taking a period from 2016-2020 publications. The data collected and recorded were the number of articles each year, the number of authors, the authors' affiliations, the city where the author works, the most productive authors, and keywords. The data was processed using Ms. Excel and the results of data processing were displayed in table form with the percentage of each variable studied. The study showed that during 2016 - 2020 the Metallurgical Journal published 78 articles, with the highest number of articles written in collaboration with 4 people ( 17 titles; $21.79 \%$ ) and at least written collaboratively by 7 people ( 8 titles; $10.25 \%)$. There were 10 articles written individually (12.82\%). The mean value of the degree of collaboration is $C=0.87$. Efendi Mabruri is the most productive writer with producing 10 titles, the most research institution contributing was LIPI with a frequency of 58 (84.06\%), while the most productive college is Sultan Ageng Tirtayasa, 24 (30.76\%), and other institutions that contributed to the writing were the Ministry of Industry and PT Petrokimia Gresik. Most authors were living in Tangerang, which is 62 (37.57\%). Most keywords are microstructure 15 times (3.51\%) and keywords containing Nickel words are $4(0.95 \%)$ Nickel Alloys, Nickel Orees 2 (0.47\%), Nickel Plating 2 (0.47\%), and Nickel Hydroxide 1 (0.23\%).

Keywords: Bibliometrics; metallurgy; nickel 


\section{INTRODUCTION}

The term bibliometrics was the first time defined by Alan Pritchard (1969) as the application of mathematics and statistical methods to books and other media. It involves analysing a series of publications characterized by the presence of bibliographic variables such as author, place of publication, subject keywords, and citations. According to Hood \& Wilson (2001), bibliometric methods and their specialization are related to informetrics, scientometrics, and webometrics. It can be used for research on various topics, such as the distribution of the frequency of use of words, phrases, in-text databases, development studies of academic disciplines, and research institutions, and citations as well. A very basic bibliometric attribute that governs the relationship between information items and activities that librarians and statisticians create to conduct bibliometric studies (Mahendra Kumar, 2014). Furthermore, according to Sulistyo-Basuki (2002) through the bibliometric method, it can be explained about the written communication process and its development in a scientific discipline.

Currently, Indonesia occupies the number one position in global nickel reserves, approximately 21 million tons. The availability of limonite nickel or low-grade nickel and saprolite nickel as high-grade nickel is quite high so that it can be used as raw material for batteries for electric vehicles (WE, 2020). Therefore, according to CNN Indonesia, the President of Republic Indonesia wanted Indonesia to be able to play in the electric car and mobile phone market. Nowadays, Indonesia is already running the nickel industry, by processing nickel or into nickel pig iron, ferronickel, and stainless steel. All this time, Indonesia has been exporting more nickel rather than processing it. In 2019, based on the records from the Ministry of Energy and Mineral Resources, nickel ore exports reached 30 million tons more than in 2018 which amounted to around 22 million tons. Nickel downstream has been started by stopping the export of nickel ore. The government banned the official export of nickel ore on January 1, 2020 (CNN Indonesia, 2021).

In supporting the government for nickel processing innovation, information about nickel research in Indonesia need to be studied and conveyed to policymakers, particularly to the Ministry of Research and Technology. This study measured the Metalurgi: Majalah Ilmu dan Teknologi (Metallurgy: Science and Technology Magazine), academic publishing covering metallurgy by using bibliometric analysis. This research continues of the research conducted by Rahayu and Nurhayati in 2017. Based on their research, it was found that (1) the distribution of metallurgical journals from 2016-2020, (2) the distribution based on the number of metallurgical journal publications in the 2016-2020 period, (3) the pattern the authorship of metallurgical journals in the 2016-2020 period, (4) the degree of collaboration of metallurgical journal authors in the 2016-2020 period, (5) the productivity of writers in metallurgical journals in the 20162020 period, (6) the universities that publish articles in the journal metallurgy for the period 2016-2020, (7) the research institutions that published articles in metallurgical journals in 20162020 , (8) the cities where the researchers are, (9) the keywords that appear in metallurgical journals 2016-2020.

This research is focused on Metalurgi: Majalah Ilmu dan Teknologi (Metallurgy: Science and Technology Magazine) published by the Indonesian Institute of Sciences Research Center for Metallurgy and Materials that can be visited at the http://ejurnalmaterialmetalurgi.com/. The scope of this journal includes advanced materials and nanotechnology, characterization and analysis of minerals and materials, extraction metallurgy, ceramics and composites, corrosion and its prevention, mineral resource processing, metallurgical and materials modelling and simulation, and metallurgical instrumentation. The Metallurgical Journal is published three times a year, namely every April, August, and December.

\section{PREVIOUS FINDINGS}

Several studies on bibliometric analysis include the following. Modern hydrometallurgy has been developing for more than 100 years and many articles have been produced. Based on research by 
Jia, LP., et al. (2020) regarding research trends and global perspectives conducted bibliometrically, it is known that based on keyword analysis, first of all, it was found that most of the research conducted was related to rare earth, recycling, lithium, ionic liquid, and thorium. Furthermore, it is also known that the proportion of bio hydrometallurgy is growing from $5 \%$ to $15 \%$, and there is a lot to say about bioleaching.

Another study was conducted by Gaurav et al., (2020). His bibliometric study has looked at research trends related to titanium metal alloys. The data were obtained from the Web of Science (WoS). A total of 1,291 articles were analyzed based on research subjects, language, total author publications, and the number of author citations. The results of his research showed that the fields of engineering and materials science were in the top place where China was the country that does a lot of research in these fields, represented by Nanjing University of Aeronautic China having the highest number of publications. The keywords that often appear were minimum quantity lubrication (MQL), nanofluid, cryogenic machining, cutting temperature, CFD, microstructure, sustainable machining, green machining, tool wear, micromachining, optimization parameters, tool life. The most frequently used new keywords were turning, mining, grinding, EDM and WEDM. This study also showed that titanium alloys were $16.94 \%$. The titanium alloy machining research received attention since 2016 and evolved gradually from year to year.

Jose Ignacio Rojas-Sola \& Angel Inocencio Aguilera Garcia in 2015 conducted a bibliometric analysis to analyze the evolution of research for the Mining \& Mineral Processing category using data from the Web of Science (WoS) from the period 1997-2012. The analysis carried out includes the number of documents, authors, average citations, research centers where the author works, country of origin, and the language of the article. The results of the analysis show that English is the most common publication language, and the United States is the most productive country although it has a relatively low impact factor. The University of Science and Technology of Beijing and the Russian Academy of Sciences are the most productive institutions in the study of this field.

Furthermore, Yang L, Wang Q, Bai X \& Deng J (2018) also researched coal in China. They used software called CiteSpace, and social network analysis for the publication period from 19712017. The information studied is in the form of information on authors, countries, institutions, journals, hot issues, and research trends in these objects. The results of their study show that: (1) Shifeng Dai, Robert B Finkelman, Guijian Liu, and James C Hower have many publications with great influence. (2) China (29.8\%) and the United States (22.2\%) have high productivity in total publications. China and the US are closely correlated in the network system of cooperation. (3) China University of Mining and Technology and Chinese Academy of Sciences are in the leading position in the number of publications among all research institutes (4) Energy and fuels, Engineering, and Environmental Sciences are the three disciplines with the most studies in this field. The International Journal of Coal Geology, Fuel, Energy and Fuels, and Fuel Processing Technology are the top four journals with the most publications in this field. (5) Origin of enrichment and mode of occurrence of trace elements is the main research related to trace elements in coal and ash. The environmental problems caused by burning coal have driven the development of trace elements in coal research, and human health has become increasingly popular in recent years. The study findings provide a better understanding of the trace element features in coal and ash research, which can be used as a reference for further studies in this field.

Other similar bibliometric studies have also been carried out by Das (2015), Garg \& Sharma (2017), Edewor (2013), Kumar (2014), Royani \& Idhani (2018), and Rahayu \& Tupan (2018). From all this, it can be seen how bibliometric studies are studies that are increasingly being carried out by academics and researchers. 


\section{RESEARCH METHODOLOGY}

The data for this bibliometric study was obtained from the Metallurgical: Science and Technology Magazine published by LIPI from the 2016-2020 period which was downloaded from the website http://ejurnalmaterialmetalurgi.com/. The focus of the study to be investigated is the frequency of the number of articles each year, the frequency of the number of articles per number, the number of authors, the collaboration of authors, the most productive authors, the institution where the author works, the city where the author works, and the research topic keywords. The data that has been obtained, then the data is processed using Ms. Excel Spread Sheet and calculate the percentage for each recorded variable. After that, the data will be interpreted, described, discussed, and finally given a conclusion.

The degree of collaboration is calculated using the formula (Subramanyam. K., 1983), which is:

\section{$\mathrm{C}=\mathrm{Nm} /(\mathbf{N m}+\mathrm{Nn})$}

Note:

$C=$ degree of collaboration

$\mathrm{Nm}=$ Total research results from researchers of a certain discipline in a certain year which are carried out in collaboration.

$\mathrm{Nn}=$ Total research results from researchers of a scientific discipline in a certain year Degree of collaboration $C=$ Level of collaboration of researchers of a discipline, with values ranging from 0 to 1.

\section{RESULTS AND FINDINGS}

Distribution of Articles by Year

Table 1. Distribution of articles by year

\begin{tabular}{ccccc}
\hline Year & Volume & $\begin{array}{c}\text { Number of } \\
\text { issues }\end{array}$ & $\begin{array}{c}\text { Number of } \\
\text { articles }\end{array}$ & (\%) \\
\hline 2016 & 31 & 3 & 17 & 21,79 \\
2017 & 32 & 3 & 16 & 20,52 \\
2018 & 33 & 3 & 15 & 19,23 \\
2019 & 34 & 3 & 15 & 19,23 \\
2020 & 35 & 3 & 15 & 19,23 \\
Total & $\mathbf{1 6 5}$ & $\mathbf{1 5}$ & $\mathbf{7 8}$ & $\mathbf{1 0 0}$ \\
Average articles per year & & & 15,60 & \\
\hline
\end{tabular}

Table 2. Articles based on the issue number

\begin{tabular}{cccccccc}
\hline \multirow{2}{*}{ Issues } & \multicolumn{7}{c}{ Volume } \\
& $\mathbf{3 1}$ & $\mathbf{3 2}$ & $\mathbf{3 3}$ & $\mathbf{3 4}$ & $\mathbf{3 5}$ & Total & $\mathbf{( \% )}$ \\
\hline 1 & 7 & 5 & 5 & 5 & 5 & 27 & 34,61 \\
2 & 5 & 6 & 5 & 5 & 5 & 26 & 33,33 \\
3 & 5 & 5 & 5 & 5 & 5 & 25 & 32,06 \\
Total & $\mathbf{1 7}$ & $\mathbf{1 6}$ & $\mathbf{1 5}$ & $\mathbf{1 5}$ & $\mathbf{1 5}$ & $\mathbf{7 8}$ & $\mathbf{1 0 0}$ \\
\hline
\end{tabular}


Authors' Collaboration

Table 3. Authors' collaboration pattern

\begin{tabular}{|c|c|c|c|c|c|c|c|c|}
\hline \multirow[b]{2}{*}{ Year } & \multicolumn{8}{|c|}{ Number of authors } \\
\hline & $\begin{array}{c}\text { One } \\
\text { author }\end{array}$ & $\begin{array}{c}\text { Two } \\
\text { authors }\end{array}$ & $\begin{array}{c}\text { Three } \\
\text { authors }\end{array}$ & $\begin{array}{c}\text { Four } \\
\text { authors }\end{array}$ & $\begin{array}{c}\text { Five } \\
\text { authors }\end{array}$ & $\begin{array}{c}\text { Six } \\
\text { authors }\end{array}$ & $\begin{array}{c}\text { Seven } \\
\text { authors }\end{array}$ & Total \\
\hline 2016 & 2 Titles & 4 Titles & 8 Titles & 1 Title & 1 Title & 1 Title & 0 Title & $\begin{array}{c}17 \\
\text { Titles }\end{array}$ \\
\hline 2017 & 2 Titles & 2 Titles & 3 Titles & 5 Titles & 2 Titles & 1 Title & 1 Title & $\begin{array}{c}16 \\
\text { Titles }\end{array}$ \\
\hline 2018 & 2 Titles & 1 Title & 3 Titles & 4 Titles & 3 Titles & 1 Title & 1 Title & $\begin{array}{c}15 \\
\text { Titles }\end{array}$ \\
\hline 2019 & 2 Titles & 1 Title & 2 Titles & 4 Titles & 3 Titles & 2 Titles & 1 Title & $\begin{array}{c}15 \\
\text { Titles }\end{array}$ \\
\hline 2020 & 2 Titles & 1 Title & 0 Title & 1 Title & 0 Titles & 4 Titles & 5 Titles & $\begin{array}{c}15 \\
\text { Titles }\end{array}$ \\
\hline Total & 10 & 9 & 16 & 17 & 9 & 9 & 8 & 78 \\
\hline
\end{tabular}

Degree of Authors Collaboration

If the value of $\mathrm{C}=0$, then it means that the article is written by a single author. If the value of $\mathrm{C}=$ 1 , it means the article is written in collaboration or with more than one author (Sormin, 2009).

Table 4. Degree of author collaboration distribution

\begin{tabular}{lllllllll}
\hline \multicolumn{1}{c}{ Pattern } & \multicolumn{8}{c}{ Year } \\
& $\mathbf{2 0 1 6}$ & $\mathbf{2 0 1 7}$ & $\mathbf{2 0 1 8}$ & $\mathbf{2 0 1 9}$ & $\mathbf{2 0 2 0}$ & Total & (\%) \\
\hline Single & 2 & 2 & 2 & 2 & 2 & 10 & 12,82 \\
Collaboration & 15 & 14 & 13 & 13 & 13 & 68 & 86,30 \\
Total & 17 & 16 & 15 & 15 & 15 & 78 & 100 \\
Degree of Collaboration & 0,88 & 0,87 & 0,86 & 0,86 & 0,86 & 0,87 & \\
& & & & & & & \\
\hline
\end{tabular}

It seems that the degree of collaboration among all publications is in the range of values 0.86 0.88 . It indicates that most of the articles are written collaboratively.

\section{Prolific Authors}

Table 5 below shows the 10 names of the most productive authors. The first is Efendi Mabruri with a total of 10 articles. He is a Research Professor at the Metallurgical Research Center of the Indonesian Institute of Sciences. He is followed by Dewa Nyoman Adnyana, a professor and lecturer from the National Institute of Science and Technology with a total of 9 papers. Then, Mochammad Syaiful Anwar and Toto Sudiro, both of them are researchers from the Metallurgical Research Center LIPI, wrote 6 articles. The other authors are shown in the following table accordingly. 
Table 5. Prolific authors

\begin{tabular}{clc}
\hline No. & \multicolumn{1}{c}{ Authors' Names } & $\begin{array}{c}\text { Numbers of } \\
\text { publication }\end{array}$ \\
\hline 1 & Efendi Mabruri & 10 \\
2 & Dewa Nyoman Adnyana & 9 \\
3 & Mochammad Syaiful Anwar & 6 \\
4 & Toto Sudiro & 6 \\
5 & Ika Kartika & 5 \\
6 & Agus Budi Prasetyo & 4 \\
7 & Latifa Hanum Lalasari & 4 \\
8 & Soesaptri Oediyani & 4 \\
9 & Aprilia Erryani & 3 \\
10 & Bambang Hermanto & 3 \\
\hline
\end{tabular}

\section{Higher education institutions}

Table 6 below shows that 13 higher education institutions have contributed to Metalurgi: Majalah Ilmu dan Teknologi for the 2006-2020 period.

Table 6. Higher education institutions

\begin{tabular}{clcc}
\hline No & \multicolumn{1}{c}{ Institutions } & $\begin{array}{c}\text { Numbers of } \\
\text { publication }\end{array}$ & (\%) \\
\hline 1 & Universitas Sultan Ageng Tirtayasa & 24 & 30,76 \\
2 & Universitas Indonesia & 11 & 14,10 \\
3 & Institut Sains dan Teknologi Nasional & 9 & 11,53 \\
4 & Universitas Gadjah Mada & 8 & 10,25 \\
5 & Institut Teknologi Bandung & 6 & 7,69 \\
6 & Universitas Parahiyangan & 4 & 5,12 \\
7 & Universitas Islam Negeri Syarif Hidayatullah & 4 & 5,12 \\
& Jakarta & & \\
8 & Universitas Jenderal Achmad Yani & 3 & 3,84 \\
9 & Universitas Diponegoro & 2 & 2,56 \\
10 & Universitas Lampung & 2 & 2,56 \\
11 & Politeknik Manufaktur Negeri Bandung & 2 & 2,56 \\
12 & Universitas Teknologi Sumbawa, Batu Alang NTB & 2 & 2,56 \\
13 & Institut Teknologi PLN & 1 & 1,28 \\
& Total & $\mathbf{7 8}$ & $\mathbf{1 0 0}$ \\
\hline
\end{tabular}

\section{Research institutions}

Table 7 shows that 3 research institutions have contributed to Metalurgi: Majalah Ilmu dan Teknologi in the period 2006-2020 as follows.

Table 7. Research institutions

\begin{tabular}{cccc}
\hline No. & Institutions & Numbers of publication & (\%) \\
\hline 1 & Lembaga Ilmu Pengetahuan Indonesia & 58 & 84,06 \\
\hline
\end{tabular}




\begin{tabular}{llcc}
\hline 2 & Badan Tenaga Nuklir Nasional & 7 & 10,15 \\
3 & Badan Pengkajian dan Penerapan Teknologi & 4 & 5,79 \\
& Total & 69 & 100 \\
\hline
\end{tabular}

Other institutions

Besides higher education and research institutions, Table 8 shows that 2 others institutions have contributed to the journal they are The Ministry of Industry of the Republic of Indonesia as many as 7 articles, and PT Petrokimia Gresik gave 1 article.

Table 8. Other institutions

\begin{tabular}{llcc}
\hline No & \multicolumn{1}{c}{$\begin{array}{c}\text { Institutio } \\
\text { ns }\end{array}$} & $\begin{array}{c}\text { Numbers of } \\
\text { publication }\end{array}$ & (\%) \\
\hline 1 & Kementerian Perindustrian RI & 7 & 87,50 \\
2 & PT Petrokimia Gresik & 1 & 12,50 \\
& Total & 8 & 100 \\
\hline
\end{tabular}

Authors' Residences

Table 9. Authors' Residences

\begin{tabular}{|c|c|c|c|}
\hline No & Authors residence & $\begin{array}{c}\text { Frekuensi } \\
\text { (kali) }\end{array}$ & (\%) \\
\hline 1 & Tangerang & 62 & 37,57 \\
\hline 2 & Bandung & 26 & 15,75 \\
\hline 3 & Cilegon & 24 & 14,54 \\
\hline 4 & Depok & 12 & 7,27 \\
\hline 5 & Jakarta & 11 & 6,66 \\
\hline 6 & Yogyakarta & 9 & 5,45 \\
\hline 7 & Lampung & 7 & 5,09 \\
\hline 8 & Semarang & 3 & 1,81 \\
\hline 9 & Sumbawa & 2 & 1,21 \\
\hline 10 & Bekasi & 1 & 0,60 \\
\hline 11 & Cimahi & 1 & 0,60 \\
\hline 12 & Gresik & 1 & 0,60 \\
\hline 13 & Indramayu & 1 & 0,60 \\
\hline 14 & Makassar & 1 & 0,60 \\
\hline 15 & Malang & 1 & 0,60 \\
\hline 16 & Medan & 1 & 0,60 \\
\hline 17 & Sleman & 1 & 0,60 \\
\hline \multirow[t]{2}{*}{18} & Surakarta & 1 & 0,60 \\
\hline & Total & 165 & 100 \\
\hline
\end{tabular}




\section{Keywords}

From the data obtained, there are 108 keywords used by all articles published in this journal, here are the results.

Table 10. Keywords

\begin{tabular}{|c|c|c|c|}
\hline No & Keywords & Total & $(\%)$ \\
\hline 1 & Microstructure & 15 & 3,51 \\
\hline 2 & Nickel & 13 & 3,09 \\
\hline 3 & Aluminum & 12 & 2,85 \\
\hline 4 & Corrosion resistance & 11 & 2,61 \\
\hline 5 & Chromium & 9 & 2,14 \\
\hline 6 & Mechanical properties & 9 & 2,14 \\
\hline 7 & Scanning electron microscopy & 9 & 2,14 \\
\hline 8 & Lithium & 8 & 1,90 \\
\hline 9 & Stainless steel & 8 & 1,90 \\
\hline 10 & Carbon steel & 7 & 1,66 \\
\hline 11 & Martensite & 7 & 1,66 \\
\hline 12 & Coal & 6 & 1,42 \\
\hline 13 & Corrosion rate & 6 & 1,42 \\
\hline 14 & Magnesium & 6 & 1,42 \\
\hline 15 & Copper alloys & 5 & 1,19 \\
\hline 16 & Hardness testing & 5 & 1,19 \\
\hline 17 & Steel & 5 & 1,19 \\
\hline 18 & Composite materials & 4 & 0,95 \\
\hline 19 & Heat treatment & 4 & 0,95 \\
\hline 20 & Leaching & 4 & 0,95 \\
\hline 21 & Limonite & 4 & 0,95 \\
\hline 22 & Metallurgical research & 4 & 0,95 \\
\hline 23 & Milling (machining) & 4 & 0,95 \\
\hline 24 & Nickel alloys & 4 & 0,95 \\
\hline 25 & Tempering & 4 & 0,95 \\
\hline 26 & Zinc alloys & 4 & 0,95 \\
\hline 27 & Carbon monoxide & 3 & 0,71 \\
\hline 28 & Corrosion inhibitors & 3 & 0,71 \\
\hline 29 & Lithium batteries & 3 & 0,71 \\
\hline 30 & Magnesium alloys & 3 & 0,71 \\
\hline 31 & Petroleum pipelines & 3 & 0,71 \\
\hline 32 & Thermal effects & 3 & 0,71 \\
\hline 33 & X-ray diffractometer & 3 & 0,71 \\
\hline 34 & Yttrium & 3 & 0,71 \\
\hline 35 & Abrasion resistance & 2 & 0,47 \\
\hline 36 & Adsorption & 2 & 0,47 \\
\hline 37 & Alloy steels & 2 & 0,47 \\
\hline 38 & Aluminum alloys & 2 & 0,47 \\
\hline
\end{tabular}




\begin{tabular}{|c|c|c|c|}
\hline 39 & Boiler tube & 2 & 0,47 \\
\hline 40 & Brain water & 2 & 0,47 \\
\hline 41 & Calcium & 2 & 0,47 \\
\hline 42 & Carbon & 2 & 0,47 \\
\hline 43 & Chromium alloys & 2 & 0,47 \\
\hline 44 & Citric acid & 2 & 0,47 \\
\hline 45 & Deposition & 2 & 0,47 \\
\hline 46 & Electromagnetics & 2 & 0,47 \\
\hline 47 & Fatigue (materials) & 2 & 0,47 \\
\hline 48 & Leak detection & 2 & 0,47 \\
\hline 49 & Microwaves & 2 & 0,47 \\
\hline 50 & Molybdenum & 2 & 0,47 \\
\hline 51 & Nickel ores & 2 & 0,47 \\
\hline 52 & Nickel plating & 2 & 0,47 \\
\hline 53 & Porous materials & 2 & 0,47 \\
\hline 54 & Roasting (metallurgy) & 2 & 0,47 \\
\hline 55 & Silicon & 2 & 0,47 \\
\hline 56 & Steam turbines & 2 & 0,47 \\
\hline 57 & Substrates & 2 & 0,47 \\
\hline 58 & Surface roughness & 2 & 0,47 \\
\hline 59 & Turbine blades & 2 & 0,47 \\
\hline 60 & X-ray diffraction & 2 & 0,47 \\
\hline 61 & Activated carbon & 1 & 0,23 \\
\hline 62 & Additives & 1 & 0,23 \\
\hline 63 & Adsorbents & 1 & 0,23 \\
\hline 64 & Aileron block & 1 & 0,23 \\
\hline 65 & Aluminizing & 1 & 0,23 \\
\hline 66 & Aluminum oxide & 1 & 0,23 \\
\hline 67 & Anneal hardening & 1 & 0,23 \\
\hline 68 & Annealing & 1 & 0,23 \\
\hline 69 & Austenite & 1 & 0,23 \\
\hline 70 & Biodegradable plastics & 1 & 0,23 \\
\hline 71 & Biomass & 1 & 0,23 \\
\hline 72 & Bismuth & 1 & 0,23 \\
\hline 73 & Boric acid & 1 & 0,23 \\
\hline 74 & Calcium sulfates & 1 & 0,23 \\
\hline 75 & Carbon dioxide & 1 & 0,23 \\
\hline 76 & Carbon nanotubes & 1 & 0,23 \\
\hline 77 & Carbonates & 1 & 0,23 \\
\hline 78 & Catalyst degradation & 1 & 0,23 \\
\hline 79 & Cavitation & 1 & 0,23 \\
\hline 80 & Cerium & 1 & 0,23 \\
\hline
\end{tabular}




\begin{tabular}{|c|c|c|c|}
\hline 81 & Chemical vapor deposition & 1 & 0,23 \\
\hline 82 & Chromium plating & 1 & 0,23 \\
\hline 83 & Coal mining & 1 & 0,23 \\
\hline 84 & Coating techniques & 1 & 0,23 \\
\hline 85 & Coatings & 1 & 0,23 \\
\hline 86 & Cobalt alloys & 1 & 0,23 \\
\hline 87 & Compressors & 1 & 0,23 \\
\hline 88 & Corrosion & 1 & 0,23 \\
\hline 89 & Corrosion protection & 1 & 0,23 \\
\hline 90 & Corrosion resistant alloys & 1 & 0,23 \\
\hline 91 & Crystal structure & 1 & 0,23 \\
\hline 92 & Crystallinity & 1 & 0,23 \\
\hline 93 & Degradation & 1 & 0,23 \\
\hline 94 & Density & 1 & 0,23 \\
\hline 95 & Diffusers & 1 & 0,23 \\
\hline 96 & Diffusion process & 1 & 0,23 \\
\hline 97 & Dryers & 1 & 0,23 \\
\hline 98 & Dye-sensitized solar cell & 1 & 0,23 \\
\hline 99 & Elbow tubes & 1 & 0,23 \\
\hline 100 & Electrodeposition coating & 1 & 0,23 \\
\hline 101 & Zirconium & 1 & 0,23 \\
\hline 102 & Polymer PLA/ABS & 1 & 0,23 \\
\hline 103 & Nanorods zink oxida, & 1 & 0,23 \\
\hline 104 & Al-Si-Cu-Fe Alloy & 1 & 0,23 \\
\hline 105 & Nickel hydroxide & 1 & 0,23 \\
\hline 106 & Magnesium & 1 & 0,23 \\
\hline 107 & Biocomposite & 1 & 0,23 \\
\hline \multirow[t]{2}{*}{108} & Al-Si-Cu-Fe alloy & 1 & 0,23 \\
\hline & Total & & \\
\hline
\end{tabular}

\section{DISCUSSION}

Based on the results and discussion, it can be concluded that in the period 2016-2020 Metallurgy: Science and Technology Magazine has published 78 articles where the most articles were written in collaboration with 4 people in 17 titles $(21.79 \%)$, and the least was written in collaboration with 7 people in 8 titles $(10.25 \%)$. There are 10 articles written individually (12.82\%). The value of the average degree of collaboration is $\mathrm{C}=-0.87$. Efendi Mabruri is the most prolific author with 10 papers. The research institution that contributed the most was LIPI with a frequency of 58 titles (84.06\%), meanwhile, the most productive university was Sultan Ageng Tirtayasa with their 24 papers $(30.76 \%)$. As for the city where the author lives, Tangerang shows the most, which is 62 authors (37.57\%). Most keywords are Microstructure (3.51\%) and keywords containing the phrase "Nickel" are Nickel alloys with 4 keywords (0.95\%), Nickel ores with 2 keywords $(0.47 \%)$, Nickel plating with 2 keywords (0.47\%), and Nickel Hydroxide with 1 keyword (0.23\%). 


\section{REFERENCES}

CNN Indonesia. (2021). Cadangan Nikel Besar, Jokowi Mau RI Main Pasar Mobil ListrikMinggu,10/01/2021 22:04 WIB. https://www.cnnindonesia.com/ekonomi/, diakses 19 Januari 2021.

Jia, L.-P., Huang, J.-J., MA, Z.-L., Liu, X-H, Chen, X-Y,Li, J-T He, L. H., Zhao, Z. W. Research and development trends of hydrometallurgy: An overview based on Hydrometallurgy literature from 1975 to 2019.Transactions of Nonferrous Metals Society of China (English Edition), 30(11), pp. 3147-3160

Gaurav, G., Sharma, A., Dangayach, G. S., (2020) Bibliometric analysis of machining of titanium alloy research. Materialstodays Proceeding: Available online 19 November 2020. In Press, Corrected ProofWhat are Corrected Proof articles?

José Ignacio Rojas-Sola \& Ángel Inocencio Aguilera-García (2015) Global Bibliometric Analysis of the 'Mining \& Mineral Processing' Subject Category From the Web of Science (19972012), Mineral Processing and Extractive Metallurgy Review, 36:6, 3 369, DOI: 10.1080/08827508.2015.1019068

Mahendra Kumar. (2014). Library Herald Journal: A Bibliometric Study. Journal of Education \& Social Policy 1(2):123-134.

Pritchard, A. 1969. Statistical bibliography or bibliometrics? Journal of Documentation, Vol. 25, no. 4: 348-349. Sormin, R. (2009). Kajian korelasi antara kolaborasi peneliti dan produktivitas peneliti lingkup Badan Litbang Pertanian. Jurnal Perpustakaan Pertanian, 18(1), 1-6.

Subramanyam. K. (1983). Bibliometric studies of research collaboration. Journal of Information Science, 6, 33-38.

Sulistyo-Basuki (2002). Pemetaan Ilmu Pengetahuan. Kumpulan Makalah Kursus Bibliometrika. Masyarakat Informetrika Indonesia. Pusat Studi Jepang, UI - Depok, 20-30 Mei 2002.

WE. (2020). Cadangan Nikel RI Terbesar di Dunia, MIND ID Bersiap Jadi Raja Baterai Mobil Listrik. Jum'at, 16 Oktober 2020, 07:55 WIB. https://www.wartaekonomi.co.id/ diakses 19Januari 2021

Yang L, Wang Q, Bai X, Deng J, Hu Y. (2018). Mapping of Trace Elements in Coal and Ash Research Based on a Bibliometric Analysis Method Spanning 1971-2017. Minerals. 2018; 8(3):89. 